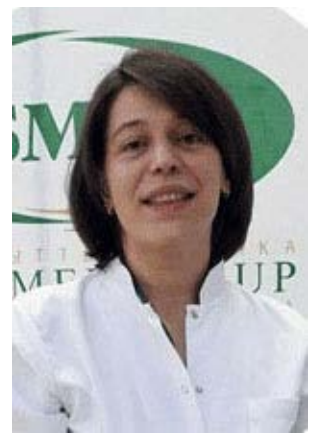

\author{
T. Shulaia ${ }^{1}$, N. Kiladze ${ }^{2}$, A. Miriamidze ${ }^{3}$ \\ ${ }^{1}$ Medical Center "Marjani", \\ ${ }^{2}$ Tbilisi State Medical University, \\ ${ }^{3}$ Pathology Research Center
}

\title{
Clear Cell Acanthoma/Pseudolymphoma: Clinical-Dermatoscopic and Histological Correlation
}

Introduction. Skin tumors are one of the most important topics in dermatology. Due to the very complex anatomy of skin, these tumors have numerous types and subtypes. The incidence of benign skin tumors is high. It is important to recognize benign tumors for excellent prevention of skin cancer. Advanced diagnostic technique of skin tumors such as dermoscopy is very useful and shows high correlation with histopathology. Dermoscopic recognition of benign tumors may help to avoid unnecessary biopsies or surgical excision. The following article provides a brief overview of the literature and presents 2 cases of two different benign tumors. One of them is a clear cell acanthoma; originally it was thought that it is a rare benign epidermal tumor of unknown etiology, however, recent studies suggest that it is a reactive inflammatory dermatosis; and the other one-pseudolymphoma which is a reactive lymphocytic proliferation appearing in the skin and resembling a malignant lymphoma [17, 19]. Both of them are rare and benign, but they present such a problem as for differentiation as well for a possibility of pseudolymphoma to transform into malignant lymphoma. Distinguishing between cutaneous pseudolymphoma and true cutaneous lymphoma requires the complete synthesis of clinical, histopathologic, immunohistochemical, and molecular data; in many situations, patients need to be followed over time (particularly patients who present with a solitary small lesion) to determine which diagnosis fits best, especially given that many cutaneous lymphomas can take months to years to fully manifest themselves clinically [7].

The aim of the study is the analysis of the overview of the accessible literature and description of two clinical cases of skin tumors from the own practice.

Materials and methods. Content analysis, method of systemic comparative analysis, bibliosemantic method of studying actual scientific researches concerning the practice of non-invasive methods of evaluation were used. The search for sources was carried out in scientific meteorological databases: PubMed-NCBI, Medline, CochraneLibrary, EMBASE, ResearchGate by keywords: "skin tumors", "clear cell acanthoma", "pseudolymphoma", "dermatoscopy".
Digital dermoscopic images were captured with a dermatoscope (DermLite DL3 dermatoscope,) mounted on a digital camera (Galaxy S-4 Samsung Corporation). Ultrasound gel was used for immersion dermatoscopy". All images were evaluated using the algorithm of H. Kittler.

The analysis of available literature data indirectly confirms the role of development of skin tumors.

Literature review and clinical cases reports. Literature review. Clear cell acanthoma is also known as Degos acanthoma or acanthome à cellules claires. Clear cell acanthoma is a rare epithelial benign tumor with unknown etiology predominantly seen on the legs of adults, mostly those in their fifties or sixties. It has also been suggested that this lesion is an inflammatory psoriasiform dermatosis [4]. Clear cell acanthoma has not been shown any gender, racial or ethnic preference. It is characterized by slow growth and may persist for years. The lesion is mostly solitary, most frequently found on the lower extremities of the middle-aged adults and elderly individuals, sometimes a few lesions may be seen. Pink-brown, slightly elevated, dome-shaped papules or plaques may have peripheral scales and erosion on the surface [9]. It is difficult to differentiate this lesion clinically from irritated seborrheic keratosis, Bowen disease, pyogenic granuloma, amelanotic melanoma, and basal cell carcinoma [18]. Diagnosis is always based on histopathologic examination. Epidermis with psoriasiform acanthosis containing large, pale (clear) keratinocytes is the main histopathologic finding. A sharp demarcation from the surrounding epidermis is the rule $[11,20]$.

Pseudolymphomas of the skin are considered to be a group of benign reactive diseases sharing some common clinical and histopathologic features with cutaneous lymphomas. However, pseudolymphomas of the skin mostly demonstrate polyclonality with proliferation of both $\mathrm{T}$ and $\mathrm{B}$ lymphocytes. It is also possible that one lineage of a cell type may be predominant. Hence these pseudolymphomas are divided into B cell or T cell. Various 
entities with different etiologies and different clinical features, including actinic reticuloid, lymphomatoid contact dermatitis, and nodular scabies are described in the spectrum of pseudolymphoma with regard to their histopathologic features [12].

Lymphocytoma cutis is a B-cell pseudolymphoma presenting with erythematous papulonodular lesions. It is mostly idiopathic but may also develop following tick bites, injections, foreign body reactions, tattoos, or acupuncture [5]. Pseudolymphomas triggered by these factors are also called the "reactive lymphoid hyperplasia" by some authors [6]. Moreover, some systemic drugs may induce the development of pseudolymphoma, and this may be called "drug-induced pseudolymphoma" [13, 15]. Borrelia burgdorferi infection may be a cause of lymphocytoma cutis in endemic areas [8]. It is more common in children and young adults, but it may occur at any age. Women are more commonly affected. The nose, cheeks, forehead and earlobes are the most common locations of lymphocytoma cutis, but it may also be seen on the scalp, chest, nipple, arms and large skin folds. Generally, it appears as a solitary lesion, but in rare instances multiple, grouped, or generalized lesions may develop [1]. Multiple lesions may be related to systemic drug use [3]. Redbrown to red-purple, dome-shaped, firm asymptomatic papules reach 0.5 to $2 \mathrm{~cm}$ size in a short time and then remain usually stable. Tiny papules with a tendency to confluence and plaques may be other presentations of pseudolymphoma. Some nodules may be lobulated. The surface of lymphocytoma cutis is usually intact [10].

Clinical differentiation from primary cutaneous lymphomas such as CD4+ small/medium pleomorphic T-cell lymphoma, and marginal zone lymphoma is difficult [2]. Granuloma faciale, nonulcerated lesions of basal cell carcinoma, and keloid may also be considered in the differential diagnosis. In addition to basic histopathologic studies immunoprofile and molecular biological diagnostic procedures should be evaluated together to establish a correct diagnosis. Predominant lymphocytic nodular infiltration without atypia accompanied by plasma cells in the superficial dermis and intermingled eosinophils, and reactive germinal centers are the main histologic hallmarks [14]. Infiltration sometimes invades the reticular dermis. As opposed to cutaneous lymphomas, monoclonality is absent, but staining with B-cell markers is predominant.

Descriptions of clinical cases. Two cases are discussed in the report. Both patients have solitary, well demarcated dome-shape, pink papulouse lesion.

Patient N, male 53 y.o. The lesion located on inner side of right leg, upper third part. It was pink shiny, well demarcated oval-shaped solitary plaque $20 \mathrm{~mm}$ in diameter, with peripheral scales on the surface and stuck round edges. Patient found this lesion 2 years ago and it had little growth on the periphery. The lesion was unsuccessfully treated as psoriatic plaque (misdiagnosis) with topical steroids; he didn't mention remission at all. This lesion was neither itchy nor painful. General condition was good, height $190.0 \mathrm{~cm}$, body weight
$97.0 \mathrm{~kg}$. The structure of the body was correct. Skin was pale, regional lymph nodes were not palpable. Laboratory test results including complete blood cell count, urine analysis, and liver function test were within normal limits. We provided digital dermoscopy examination, which has shown that the most characteristic is the pattern of blood vessels. Linear pattern of vessels were observed on the periphery, on the central part, multiple dotted vessels arranged partly in linear, pearl-like distribution and partly in reticular appearance. These dotted vessels, which represent the dilated capillaries, oriented mainly perpendicular to the skin surface in the elongated dermal papillae, formed a reticular appearance due to the regular distribution over the surface. Additionally, the multiple dotted vessels were circumscribed by a translucent collarette scaling (fig. 1). In pathology images, acanthotic epidermis containing larger than usual keratinocytes ( $\sim 2 \mathrm{x}$ normal epidermal keratinocytes) are seen, well demarcated from adjacent epidermis. Also hypergranulosis, minimal nuclear pleomorphism, the vessels within the dermal papillae are dilated, tortuous and run vertically up the papillae (fig. 2).
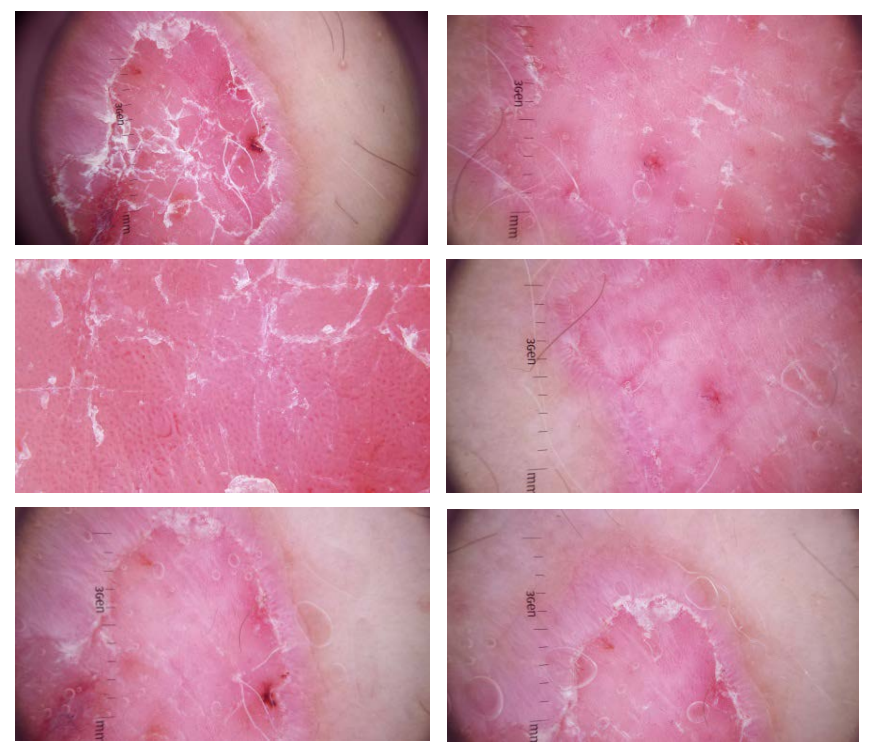

Fig. 1 .
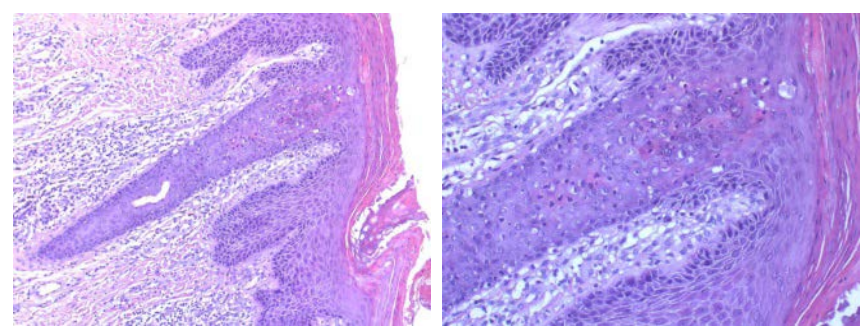

Fig. 2.

The second case is presented by 37 year - old female, who came to the outpatient clinic with main complaints of fast growing pink solitary lesion on the left eyebrow. General condition was satisfactory, consciousness was clear, gait was not broken. Height $-167.0 \mathrm{~cm}$, body weight $-61.0 \mathrm{~kg}$. During clinical examination, a lesion 
were found on the face. The lesion was presented by pink dome-shaped papule, with sharply demarcated boarders on left eyebrow, located on the medial edge, size $7 \times 7 \mathrm{~mm}$ (fig. 1,2). Under dermatoscopy examination we observed homogenic structurless pink area, with reticular white lines, no chaos in pattern (fig. 3). Histology shows a nodular inflammatory infiltrate in the dermis. An infiltrate containing middle size, wellformed lymphocytes with hyperchromic nuclear located mostly in the papillary and upper reticular dermis (top-heavy) favors pseudolymphoma. The key histologic features favoring pseudolymphoma include the presence of a mixed infiltrate that includes histiocytes, eosinophils, and plasma cells, in addition to lymphocytes, no deep invasion, no prominent sclerosis was marked. Was prepared immunohistochemistry study with CD20, Ki67, CD3, CD5, CD43 was prepared. In the dermis, CD20 positive small B lymphocytes formating infiltration and containing in $\sim 5 \% \mathrm{Ki} 67$ positive germinal centers limited to the papillary and upper reticular dermis (topheavy) indicating pseudolymphoma, and a large number CD3, CD5, CD43 positive small sized $\mathrm{T}$ lymphocytes infiltration were found (fig. 4).
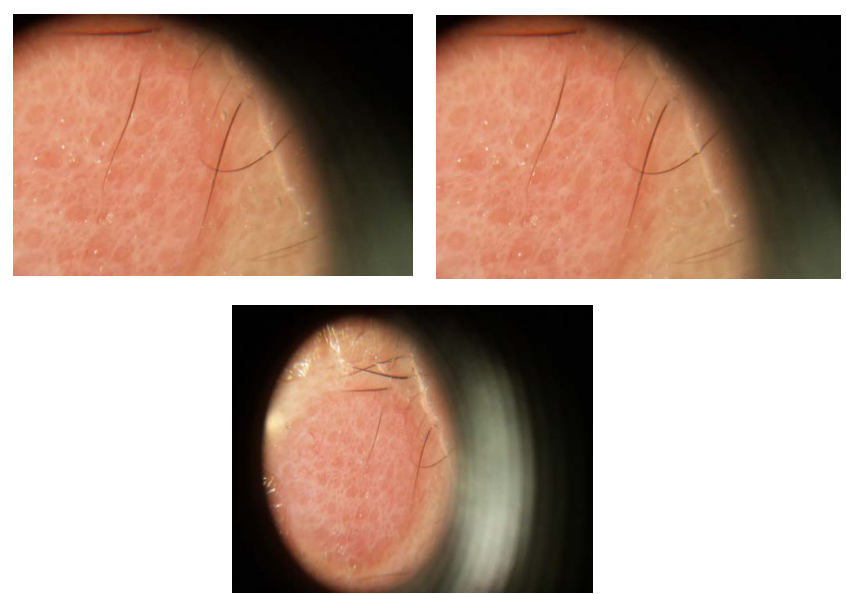

Fig. 3 .
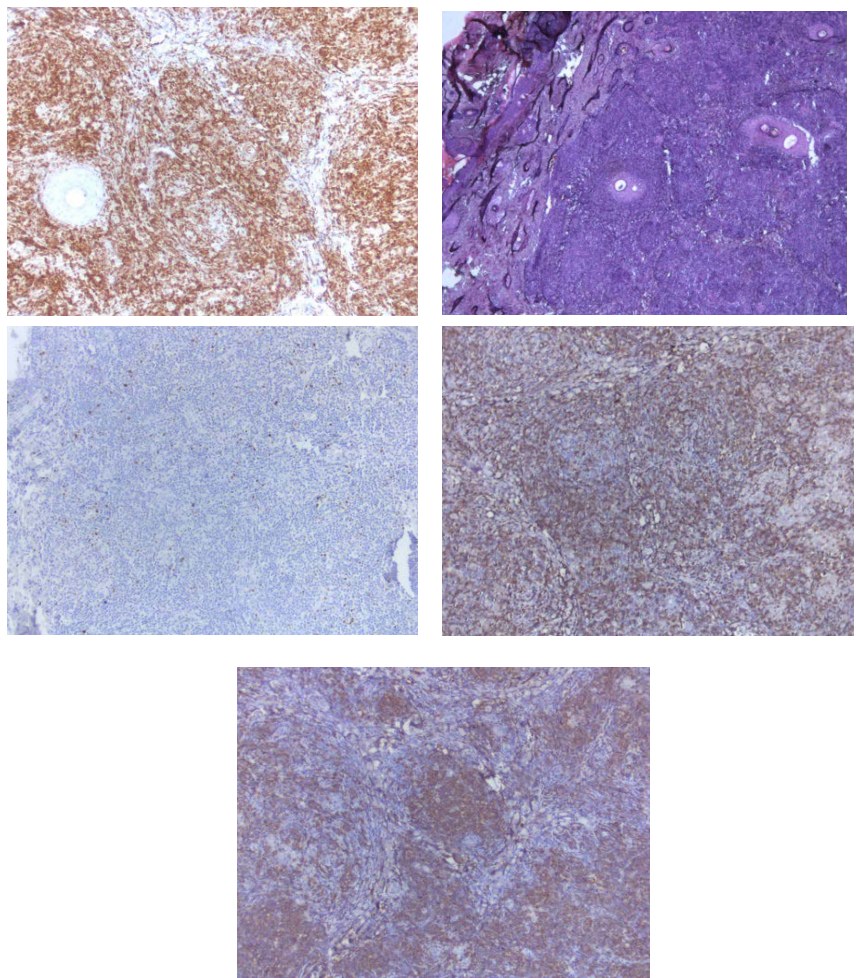

Fig. 4.

Conclusions. An overview of the modern literature and clinical presentations from our own practice suggests that clinically similar pink solitary skin lesions can be recognized by advanced dermoscopy examination. Der moscopic recognition of benign tumors may help to avoid unnecessary biopsies or surgical excision. Careful clin ical and dermatoscopy monitoring gives additional ben efits for better recognition of skin tumors, but, of course in case of suspicious lesions special tests like histology from a skin biopsy, immunohistochemical stains and/or electron microscopy must be done. This kind of studies will be useful for better dermatoscopy description and make easier diagnostic of skin tumors.

\section{REFERENCES}

1. Потекаев НС, Сергеев ЮВ. Псевдолимфомы кожи. Медицинский реферативный журнал. 1978;11:13-19 (Potekaev NS, Sergeev YV. Skin Pseudolymphomas. Medical Abstract Journal. 1978;11:13-19). (Russian).

2. Ackerman AB, Breza TS, Capland L. Spongiotic simulants of mycosis fungoides. Arch Dermatol. 1974;109(2):218-219. https://doi.org/10.1001/archderm.1974.01630020034008

3. Aguilar JL, Barcelo CM, Martin-Urda MT, Rodellas AC. Generalized cutaneous pseudolymphoma induced by neuroleptics. Arch Dermatol. 1992;128(1):121-123. https://doi.org/10.1001/archderm.1992.01680110135026

4. Blum A, Metzler G, Bauer J, Rassner G, Garbe C. The dermatoscopic pattern of clear-cell acanthoma resembles psoriasis vulgaris. Dermatology. 2001;203:50-52. https://doi.org/10.1159/000051703

5. Blumental G, Okun MR, Ponitch JA. Pseudolymphomatous reaction to tattoos. J Am Acad Dermatol. 1982;6(4 Pt 1):485488. https://doi.org/10.1016/S0190-9622(82)70041-6

6. Bocquet H, Bagot M, Roujeau JC. Drug-indced pseudolymphoma and drug hypersesivity syndrome (Drug Rash with Eosinophilia and Systemics Symptoms: DRESS). Semin Cutan Med Surg. 1996;15(4):250-257. https://doi.org/10.1016/ S1085-5629(96)80038-1

7. Can Baykal, Didem Yazganog K. Clinical Atlas of Skin Tumors. Springer, 2014. 499 p. https://doi.org/10.1007/978-3642-40938-7

8. Ecker RI, Winkelmann RK. Lymphomatoid contact dermatitis. Contact Dermat. 1981;7(2):84-93. https://doi.org/ 10.1111/j.1600-0536.1981.tb03985.x

9. Figen Yazkan Akin, Ilgen Ertam, Can Ceylan, Alican Kazandi, Fezal Ozdemir. Clear cell acanthoma: New observations on dermatoscopy. Department of Dermatology, Ege University Medical Faculty. Bornova-Izmir, Turkey; 2008;74(3 issue):285-287. https://doi.org/10.4103/0378-6323.41396 
10. Gupta AK, Cooper KD, Ellis CN, Nickoloff BJ, Hanson CA, Brown MD et al. Lymphocytic infiltrates of the skin in association with cyclosporine therapy. J Am Acad Dermatol. 1990;23(6 Pt 1):1137-1141. https://doi.org/10.1016/01909622(90)70347-K

11. Lyons G, Chamberlain AJ, Kelly JW. Dermoscopic features of clear cell acanthoma: five new cases and a review of existing published cases. Australas J Dermatol. 2015;56(3):206-211. https://doi.org/10.1111/ajd.12206

12. Harris DW, Ostlere L, Buckley C, Whittaker S, Sweny P, Rustin MH. Phenytoin-induced pseudolymphoma. A report of a case and review of the literature. Br J Dermatol. 1992;127(4):403-406. https://doi.org/10.1111/j.1365-2133.1992. tb00463.x

13. Kardaun SN, Scheffer E, Vermeer BJ. Drug-induced pseudolymphomatous skin reactions. Br J Dermatol. 1988;118(4):545552. https://doi.org/10.1111/j.1365-2133.1988.tb02465.x

14. Magro CM, Crowson PN. Drugs with antihistaminic properties as a cause of atypical cutaneous limphoid hyperplasia. J Am Acad Dermatol. 1995;32(3):419-428. https://doi.org/10.1016/0190-9622(95)90063-2

15. Sigal M, Pulic M. Pseudolymphomes medicamenteux a expression cutanee predominate. Ann Dermatol Venerol. $1993 ; 120(2): 175-180$.

16. Wall LM. Lymphomatoid contact dermatitis due to ethylenediamine dihydrochloride. Contact Dermatitis. 1982;8(1):5154. https://doi.org/10.1111/j.1600-0536.1982.tb04135.x

17. Charlesworth EN. Phenytoin-induced pseudolymphoma syndrome: an immunologic study. Arch Dermatol. 1977;113(4):477-480. https://doi.org/10.1001/archderm.1977.01640040085013

18. Zalaudek I, Hofmann-Wellenhof R, Argenziano G. Dermoscopy of clear-cell acanthoma differs from dermoscopy of psoriasis. Dermatology. 2003;207(4):428-429. https://doi.org/10.1159/000074137

19. Zalaudek I, Kreusch J, Giacomel J, Ferrara G, Catricalà C, Argenziano G. How to diagnose nonpigmented skin tumors: a review of vascular structures seen with dermoscopy: part I. Melanocytic skin tumors. J Am Acad Dermatol. 2010;63(3):361-374. https://doi.org/10.1016/j.jaad.2009.11.698

20. Zalaudek I, Kreusch J, Giacomel J, Ferrara G, Catricalà C, Argenziano G. How to diagnose nonpigmented skin tumors: a review of vascular structures seen with dermoscopy: part II. Nonmelanocytic skin tumors. J Am Acad Dermatol. 2010;63(3):377-386. https://doi.org/10.1016/j.jaad.2009.11.697

Стаття надійшла до редакції журналу 04.02.2019 р.

\title{
Світлоклітинна акантома/псевдолімфома: клініко-дерматоскопічні та гістологічні кореляції
}

\author{
Т. Шулаіа, Н. Кіладзе, А. Міріамідзе
}

Вступ. Серед новоутворень у людини пухлини шкіри є чи найчисленнішою групою, що зумовлено складною структурою цього органа. Доброякісні пухлини шкіри - одна 3 найпоширеніших патологій, що посідає проміжне місце на стику дерматологіï, онкологіï та хірургіï, а їх своєчасна діагностика та видалення важливі не тільки для цих трьох спеціальностей, а й для загальної лікувальної практики. Диференційна діагностика таких новоутворень досі актуальна, і різноманіття методів діагностики не розв' язує проблему. Найбільш доступним методом оптичної діагностики шкіри є дерматоскопія, неінвазивність і простота якої зробили іï незамінною в сучасній практиці. Розглянуто дерматоскопічні характеристики та кореляцію їх із патоморфологічними результатами дослідження двох випадків із власної практики - світлоклітинної акантоми та псевдолімфоми. Обидві пухлини трапляються рідко, обидві доброякісні та є проблемними для діагностики й диференціації.

Мета. Здійснити аналіз доступної літератури та опис клінічних випадків із власної практики.

Матеріали й методи. Використано контент-аналіз, метод системного та порівняльного аналізу, бібліосемантичний метод вивчення актуальних наукових досліджень. Пошук джерел здійснено в наукометричних медичних базах інформації: PubMed-NCBI, Medline, CochraneLibrary, EMBASE, ResearchGate за ключовими словами: світлоклітинна акантома, псевдолімфома, дерматоскопія. Дерматоскопічні зображення отримано за допомогою дерматоскопа DermLite DL3, закріпленого на цифрову камеру (Galaxy S-4 Samsung Corporation). Для імерсійної дерматоскопії застосовували ультразвуковий гель. Усі зображення оцінені з використанням алгоритму Г. Кіттлера.

Результати. Світлоклітинна акантома - рідкісна доброякісна епітеліальна пухлина з нечіткою етіологією. Вважається, що виникає внаслідок порушення дозрівання кератиноцитів. Уперше ії описав і виокремив як самостійну нозологічну одиницю Дегос. Деякі автори вважають, що це не пухлина, а місцевий гіперпластичний процес. Світлоклітинна акантома частіше виникає у людей похилого віку як солітарний вузол до 2 см у діаметрі, розташований зазвичай на нижніх кінцівках, частіше на гомілках. Диференційна діагностика проводиться з дерматофібромою, ліхеноїдним кератозом, базаліомою, піогенною гранульомою, важко диференціюється з подразненим себорейним кератозом та безпігментною меланомою. Дерматоскопічного дослідження може бути замало. Для остаточного діагнозу необхідне підтвердження патоморфологічними показниками. 
Псевдолімфома шкіри - реактивний дерматоз, що нагадує лімфому як клінічно, так і гістологічно, але має доброякісний перебіг і тенденцію до спонтанного регресу. Зазвичай виникнення псевдолімфоми шкіри провокують різноманітні екзогенні, рідше ендогенні чинники. Псевдолімфоми шкіри вважають групою доброякісних реактивних захворювань, що мають подібні не тільки клінічні, але й гістопатологічні особливості зі шкірними лімфомами. Проте псевдолімфоми шкіри переважно демонструють поліклональність із проліферацією як Т-, так і В-лімфоцитів. Також імовірно, що один тип клітин може переважати.

Клінічна диференціація від первинних шкірних лімфом, таких як CD4+ мала/середня плеоморфна Т-клітинна лімфома та лімфома в периферійній зоні, утруднена, тому діагностика вимагає дерматоскопії та патоморфологічного дослідження.

У двох наведених випадках у пацієнтів були добре демарковані рожеві вузли напівсферичної форми. У першому випадку вузол розташований на внутрішній поверхні шкіри верхньої третини правої нижньої кінцівки. Вузол рожевого кольору, до 20,0 мм діаметром, із округлими краями та лущенням на периферії, неболючий. Вузол існує два роки, його безуспішно лікували місцевими стероїдами. При дерматоскопічному дослідженні у випадку світлоклітинної акантоми найбільш характерним був рисунок судин. По периферії виявлено лінійні рисунки судин, у центральній частині - візерунок множинних точкових судин, розташованих частково за лінійним і частково за ретикулярним типом. Точкові судини, які були розширеними капілярами, орієнтовані перпендикулярно до поверхні шкіри і створюють ретикулярний візерунок, завдяки регулярному розподілу по поверхні. Крім цього, довкола множинних точкових судин зафіксовано прозору облямівку з лущенням. Морфологічне дослідження показало акантоз у епідермісі, кератиноцити більших розмірів, ніж звичайно, гіпергранульоз, мінімальний нуклеарний поліморфізм, судини в дермальних сосочках розширені й проходять вертикально. У другому випадку на шкірі обличчя біля лівої брови наявна напівсферичної форми папула рожевого кольору з чіткими краями розміром $7 \times 7$ мм, яка демонструвала швидкий ріст. Дерматоскопічним дослідженням виявлено безструктурну рожеву ділянку, ретикулярні білі лінії та відсутність хаосу.

Патоморфологічне дослідження показало вузловий інфільтрат у ретикулярній і папілярній дермі. Ключовими гістологічними особливостями на користь псевдолімфоми $є$ наявність змішаного інфільтрату, що включає гістіоцити, еозинофіли і плазматичні клітинки, неглибока інвазія, відсутність клітинного поліморфізму та вираженого склерозу.

Висновки. Огляд сучасної літератури та клінічні випадки з власної практики дають змогу припустити, що клінічно подібні поодинокі інфільтративні ураження шкіри можуть бути визначені попереднім дерматоскопічним дослідженням. Ретельний клінічний і дерматоскопічний моніторинг надає додаткові переваги для кращого розпізнавання пухлин шкіри, хоча незрозумілі випадки вимагають патоморфологічного дослідження.

Ключові слова: світлоклітинна акантома, псевдолімфома, дерматоскопія.

\section{Clear Cell Acanthoma/Pseudolymphoma: Clinical-Dermatoscopic and Histological Correlation}

\section{T. Shulaia, N. Kiladze, A. Miriamidze}

Introduction. Skin tumors make up the largest group due to the complex structure of this organ. Benign skin tumors are one of the most common pathologies that occupy an intermediate position at the interface of dermatology, oncology and surgery, and their timely diagnosis and removal are important not only for these three specialties, but also for the general medical network. Differential diagnosis of such tumors is still an urgent problem, and a variety of diagnostic methods does not solve the problem. Today, the most affordable method of optical diagnostics of the skin is dermatoscopy, the non-invasiveness and simplicity of which made it indispensable in modern practice. The article describes dermatoscopic characteristics and their correlation with the data of pathomorphological studies in two cases from our own practice - clear cell acanthoma and pseudolymphoma. Both of these tumors are rare, benign, and present certain difficulties for diagnosis.

The aim of the study. Analysis of available literature and the description of clinical cases from own practice.

Materials and methods. Content analysis, method of system and comparative analysis, bibliosemantic method of studying of relevant scientific research were used. The search for sources was carried out in scientometric medical information bases: PubMed-NCBI, Medline, CochraneLibrary, EMBASE, ResearchGate in accordance with the keywords: clear cell acanthoma, pseudolymphoma, dermatoscopy. Digital dermatoscopy images were obtained using a dermatoscope (DermLite DL3 dermatoscope) attached to a digital camera (Galaxy S-4 Samsung Corporation). For the immersion dermatoscopy ultrasound gel was used. All obtained images were estimated in accordance with the algorithm of G. Kittler. 
Results. Clear cell acanthoma is a rare benign epithelial tumor with unclear etiology. It is believed that the basis of its development is an impaired keratinocyte maturation. Some authors do not refer it to tumors, but consider that this is a local hyperplastic process. Clear cell acanthoma often develops in the elderly as a single node up to $2 \mathrm{~cm}$ in diameter, usually found on the lower extremities, most commonly on the legs. Differential diagnosis should be carried out with dermatofibroma, lichenoid keratosis, basalioma, pyogenic granuloma. Differential diagnosis with irritated seborrheic keratosis and non-pigmented melanoma is difficult. Dermatoscopic examination can be insufficient, the pathomorphological conclusion is necessary for the final diagnosis. The pseudo-lymphoma of the skin is a reactive dermatosis, resembling lymphoma both clinically and histologically, but has a benign course and a tendency to spontaneous regression, therefore, for a differential diagnosis, dermatoscopy and pathological examination are necessary. Two cases from own practice were presented in the work; clearly distinguished pink hemispherical nodes were observed in both patients. During the dermatoscopic examination, two different tumors were diagnosed - clear cell acanthomas and pseudolymphomas, in both cases the dermatoscopic indicators corresponded to the pathological conclusion.

Conclusions. An overview of modern literature and clinical cases from our own practice suggests that clinically similar single infiltrative skin lesions can be identified by previous dermatological studies. Careful clinical and dermatological monitoring provides additional benefits for better recognition of skin tumors, although unclear cases require a pathomorphological study.

Keywords: clear cell acanthoma, pseudolymphoma, dermatoscopy. 